\title{
Bioinspired total synthesis of katsumadain A by organocatalytic enantioselective 1,4-conjugate addition
}

Yongguang Wang, Ruiyang Bao, Shengdian Huang and Yefeng Tang*

\section{Letter}

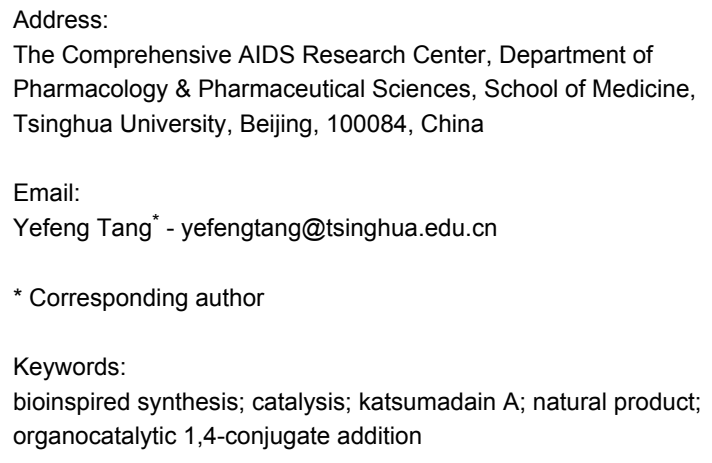

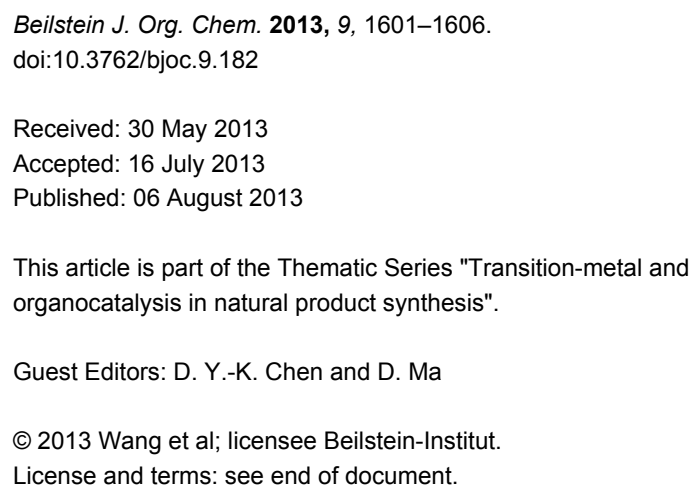

\begin{abstract}
Katsumadain A, a naturally occurring influenza virus neuraminidase (NA) inhibitor, was synthesized by using a bioinspired, organocatalytic enantioselective 1,4-conjugate addition of styryl-2-pyranone with cinnamaldehyde, followed by a tandem Horner-Wadsworth-Emmons/oxa Michael addition.
\end{abstract}

\section{Introduction}

2-Pyranone is a privilege structure that is often present in natural products and pharmaceuticals, many of which exhibit diverse molecular architectures and biological profiles [1,2]. For example, katsumadain A (1) and B (2), which were isolated from Alpinia katsumadai Hayata (Zingiberaceae), a chinese herbal drug used as an anti-emetic and stomachic agent, are two natural products bearing a diarylheptanoid scaffold that is incorporated into the styryl-2-pyranone moiety [3]. Preliminary biological evaluations showed that $\mathbf{1}$ and $\mathbf{2}$ feature anti-emetic activities on copper sulfate-induced emesis in young chicks. More recently, Rollinger et al. disclosed that katsumadain A (1) exhibited prominent in vitro inhibitory activity against the human influenza virus $\mathrm{A} / \mathrm{PR} / 8 / 34$ of the subtype $\mathrm{H} 1 \mathrm{~N} 1$ ( IC $_{50}$ $1.05-0.42 \mu \mathrm{M}$ ) by targeting the enzyme neuraminidase (NA) $[4,5]$. Moreover, it also inhibited the NA of four H1N1 swine influenza viruses with $\mathrm{IC}_{50}$ values between 0.59 and $1.64 \mu \mathrm{M}$. Therefore, katsumadain A represents an attractive lead structure for the anti-flu drug discovery [6].

We recently reported the biomimetic total synthesis of katsumadain $\mathrm{C}$ [7], a natural product isolated from the same resource as katsumadain A and B [8]. As part of our continuous interest in the synthesis of bioactive 2-pyranone-derived natural products, we launched a project aiming to develop a highly effi- 
cient route for the synthesis of katasumadain A as well as its analogues, which would pave the way for their application in further biomedical investigations.

Biosynthetically, katsumadain A is assumed to be derived from styryl-2-pyranone 3 and alnustone (4) [9] through a 1,6-conjugate addition/oxa-Michael addition cascade reaction (path a, Scheme 1). Indeed, both $\mathbf{3}$ and $\mathbf{4}$ are known natural substances. Apparently, the biosynthetic pathway represents the most straightforward and convergent approach to synthesize katsumadain A. However, its efficiency might be limited to some extent, given that $\alpha, \beta, \gamma, \delta$-unsaturated ketone 4 could undergo a competitive 1,4-conjugate addition to provide the other natural product katsumadain B (path $b$, Scheme 1). Actually, the regioselectivity of a conjugate addition with $\alpha, \beta, \gamma, \delta$ unsaturated Michael acceptors remains a considerable challenge, as it is heavily dependent on the steric and electronic nature of the substrates $[10,11]$. Moreover, the enantioselective 1,6-conjugate addition to acyclic dienones or dienoates monosubstituted at the $\beta$ - and $\delta$-position has rarely been investigated [12-15], thus leaving open the question of whether or not a biomimetic approach towards katsumadain A might succeed. Keeping these concerns in mind, an alternative strategy was designed as a fallback, in which katsumadain A could be accessed from the lactol 5a and phosphonate $\mathbf{6}$ via a tandem Horner-Wadsworth-Emmons (HWE)/oxa-Michael addition reaction [16]. In turn, 5a could be derived from $\mathbf{3}$ and cinnamaldehyde (7) by an organocatalytic enantioselective 1,4conjugate addition followed by the hemiketal formation.

\section{Results and Discussion}

Our investigation was initiated by an investigation of the conditions that could effect the proposed biomimetic approach towards katsumadain A and katsumadain B. Both styryl-2-pyranone 3 [17] and alnustone (4) [18] were synthesized according to the literature methods. First of all, the 1,6-conjugate addition of $\mathbf{3}$ towards $\mathbf{4}$ was attempted by employing various conditions, including different basic conditions (NaH, DBU, KHMDS) by activation of the nucleophile 3 or acidic conditions $(\mathrm{AcOH}$, TMSOTf, $\operatorname{Sc}(\mathrm{OTf})_{3}$ and $\left.\operatorname{In}(\mathrm{OTf})_{3}\right)$ by activation of the electrophile 4. However, all of these reactions failed to provide satisfactory results and only lead to the recovery or the substantial decomposition of the starting material. We then turned our attention to the organocatalytic conjugated addition reaction. Among the various documented conditions [19-23], the 9-amino-9-deoxyepicinchona alkaloid-promoted Michael addi-

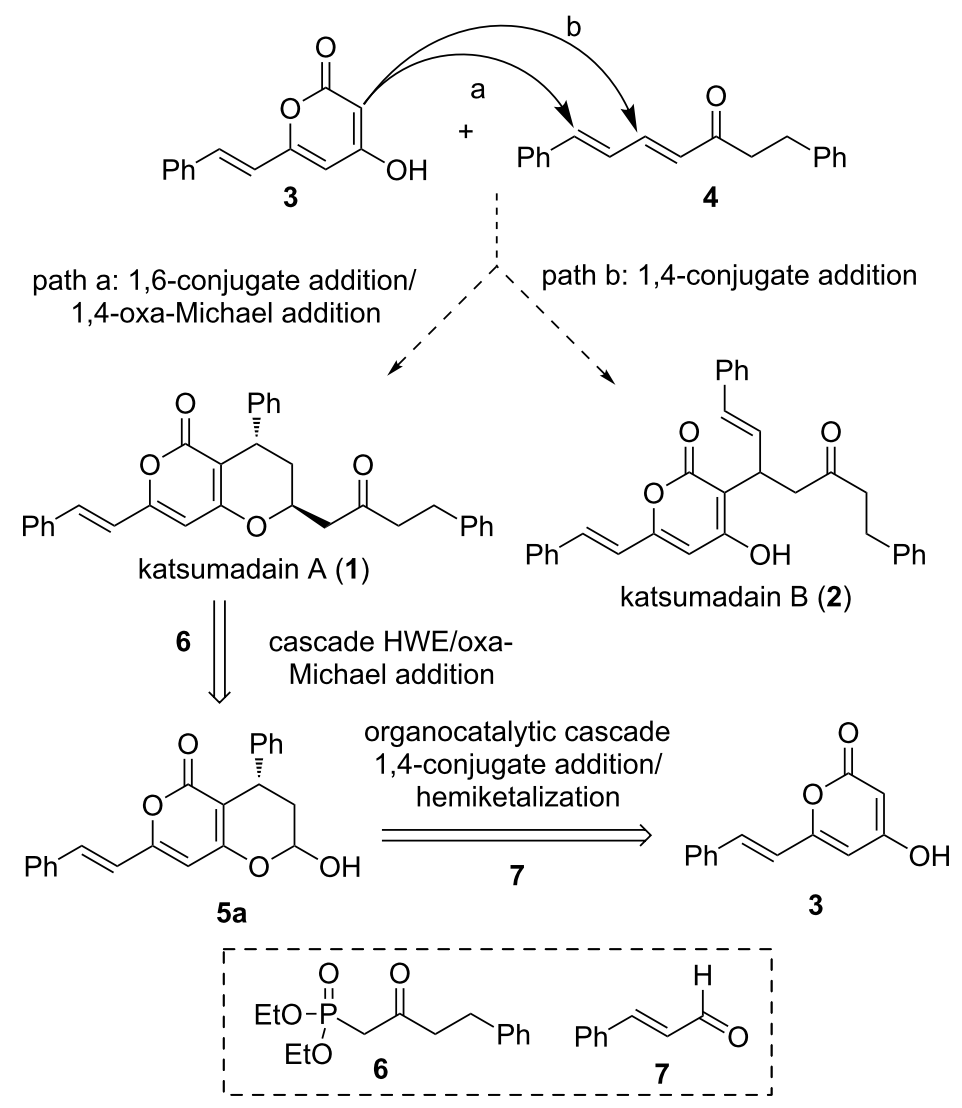

Scheme 1: Proposed biosynthetic pathway and strategic analysis for synthesis of katsumadain A. 
tion is particularly attractive, mainly due to the availability of the catalyst and its superior reactivity towards the activation of the unsaturated ketone substrates through formation of the corresponding iminium intermediate [22]. To our delight, when we tried the standard conditions ( $30 \%$ catalyst $\mathbf{A}, 60 \%$ TFA, DCM, $96 \mathrm{~h}$ ) in our case, we isolated a product in $25 \%$ isolated yield, which was proved to be the 1,4-adduct katsumadain B (2). Encouraged by this result, we further optimized the reaction by screening different solvents $\left(\mathrm{CH}_{3} \mathrm{CN}\right.$, THF, DMSO and $\mathrm{MeOH})$ and additives ( $\mathrm{HCl}$, TFA and DMAP), aiming to improve the efficiency and selectivity (1,4- or 1,6-adduct) of the reaction. In most of the cases the 1,4-conjugate addition proceeded dominantly, while no or only trace amounts of the 1,6-adduct katsumadain A (1) was observed. The best result was obtained when the reaction was performed with a substoichiometric amount of catalyst $\mathbf{A}$ with $\mathrm{MeOH}$ as a solvent, in which katsumadain $\mathrm{A}$ and $\mathrm{B}$ were isolated in a 5:6 ratio with a combined yield of $33 \%$ (Scheme 2).

With limited success regarding the the biomimetic synthesis of katsumadain A, we then moved towards the alternative approach as described in Scheme 1. We envisioned that in this scenario an organocatalytic 1,4-conjugate addition [24-27] between 3 and 7 would circumvent both the reactivity and

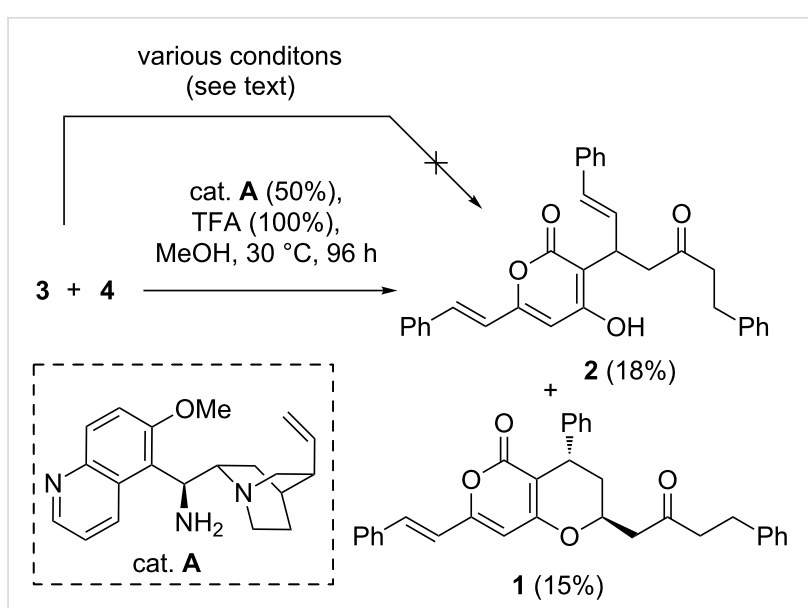

Scheme 2: Preliminary results of the biomimetic synthesis of katsumadain $\mathrm{A}$.

selectivity issues, which we have struggled with in the aforementioned studies. To validate this hypothesis, we performed a systematic investigation of the organocatalytic 1,4-conjugate addition by examining various reaction parameters, including organocatalyst, acid additive, solvent temperature, and reaction temperature (Table 1). The first reaction was performed by stirring a mixture of $\mathbf{3}$ and $\mathbf{7}$ in DCM at room temperature for $12 \mathrm{~h}$

Table 1: Condition screening of organocatalytic 1,4-conjugate addition/hemiketalization of styryl-2-pyranone with $\alpha, \beta$-unsaturated aldehydes.

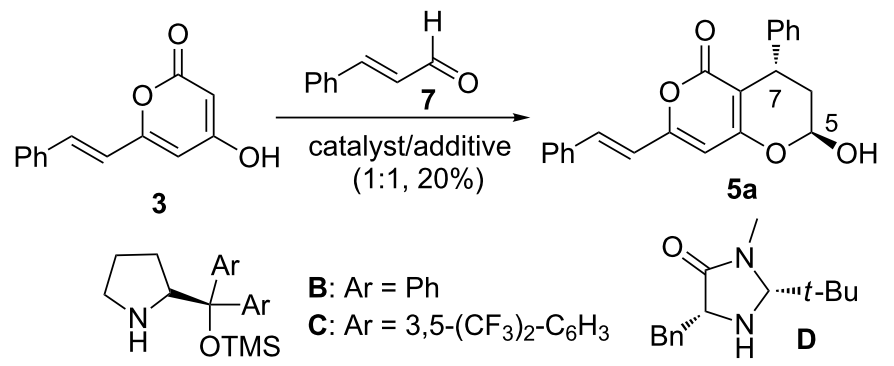

\begin{tabular}{lllllll}
\hline Entry & Catalyst & Additive & Solvent & $T\left({ }^{\circ} \mathrm{C}\right)$ & Yield $(\%)$ & ee $(\%)^{\mathrm{b}}$ \\
\hline 1 & B & none & DCM & 23 & 41 & 78 \\
2 & B & BA & DCM & 23 & 78 & 91 \\
3 & C & BA & DCM & 23 & 41 & -81 \\
4 & D & BA & DCM & 23 & 10 & nd \\
5 & B & PNBA & DCM & 23 & 94 & 80 \\
6 & B & BA & MeOH & 23 & 80 & 91 \\
7 & B & BA & $\mathrm{CH}_{3} \mathrm{CN}$ & 23 & 78 & 75 \\
8 & B & BA & DMSO & 23 & 79 & 93 \\
9 & B & BA & Toluene & 23 & 66 & 91 \\
10 & B & BA & MeOH & 0 & 78 & 92 \\
11 & B & BA & DCM & 0 & 82 & 92 \\
12 & B & BA & DCM & -20 & 45 & 93 \\
\hline
\end{tabular}

aEach reaction was run with $3(0.5 \mathrm{mmol})$ and $7(0.6 \mathrm{mmol})$ in $2.0 \mathrm{~mL}$ solvent as shown above. ${ }^{\mathrm{b}}$ The ee value was measured with the corresponding lactone product of 5 a using chiral HPLC. 
in the presence of Hayashi catalyst $\mathbf{B}$ [28]. It was found that the desired product 5a was obtained, albeit in moderate yield and enantioselectivity (Table 1, entry 1). To our delight, the usage of benzoic acid (BA) as an additive could dramatically improve the reaction by affording $\mathbf{5 a}$ in a good yield (78\%) and a good ee value ( $91 \%$, Table 1 , entry 2$)$. Besides the catalyst $\mathbf{B}$, both Jørgensen catalyst $\mathbf{C}$ [29] and MacMillan catalyst D [30] were also tested in this reaction, but gave inferior results (Table 1 , entries 3 and 4). As to the acid additive, $p$-nitrobenzoic acid (PNBA) was found to afford 5a in an excellent yield, but with a decreased ee value (80\%). Furthermore, the solvent effect was also examined. Among the several solvents examined, both $\mathrm{MeOH}$ and DMSO proved to be suitable solvent systems (Table 1, entries 6 and 8 ) by furnishing comparable results with $\mathrm{DCM}$, while $\mathrm{MeCN}$ and toluene led to modest results (Table 1, entry 7 and 9). Finally, we found that the reaction temperature has some influence on the outcomes, with a slightly improved enantioselectivity ( $92 \%$ ee) obtained at $0{ }^{\circ} \mathrm{C}$ (Table 1 , entry 10 and 11$)$. Although the best ee value $(93 \%)$ was achieved at $-20{ }^{\circ} \mathrm{C}$, the reaction became sluggish and the yield dropped to $45 \%$ (Table 1, entry 12). It is noteworthy that $\mathbf{5 a}$ was isolated as a mixture of C- 5 diastereoisomers $(\beta$-isomer $/ \alpha$-isomer $=5: 1$ to $7: 1)$ in all of the above cases. For convenience, the ee value of 5a was determined with the corresponding lactone derivative. Furthermore, the absolute stereochemistry of 5a ( $\beta$-isomer) was assigned as $(7 S, 5 R)$ by using the Mosher ester method (see Supporting Information File 1 for details).
To evaluate the substrate scope of the reaction, we then examined different substituted styryl-2-pyranone and cinnamaldehyde derivatives as Michael addtion donors and acceptors (Table 2). When styryl-2-pyranone 3a remained unchanged, a variety of cinnamaldehyde derivatives $(\mathbf{7 a}-\mathbf{f})$ bearing either electron-withdrawing groups (4-Cl, 4- $\mathrm{CF}_{3}$ and $4-\mathrm{NO}_{2}$, Table 2 , entries 2-4) or electron-donating groups (4- $\mathrm{MeO}$ or 3,5-MeO, Table 2, entries 5 and 6 ) on the phenyl ring proved to be suitable substrates, affording the corresponding products $(\mathbf{5 b}-\mathbf{f})$ in good yields and enantioselectivities. Besides 3a, the Michael addition donors could also be extended to other substituted styryl-2-pyranone derivatives (e.g., 3b and 3c, Table 2, entries 7-11), all of which gave acceptable results. As proof-of-concept cases, the above outcomes indicate that the developed organocatalytic enantioselective 1,4-conjugate addition could be potentially applied to the synthesis of various bicyclic compounds bearing different aromatic moieties $\left(\mathrm{Ar}^{1}\right.$ and $\left.\mathrm{Ar}^{2}\right)$, which paves the way to access katsumadain $\mathrm{A}$ and its analogues for further biomedical studies.

Having achieved the bicyclic core of katsumadain A in an efficient and enantioselective manner, we then moved towards its total synthesis through the proposed tandem Horner-Wadsworth-Emmons/oxa-Michael addition. As expected, deprotonation of 6 [31] with KHMDS at $-40{ }^{\circ} \mathrm{C}$ for $0.5 \mathrm{~h}$ followed by the addition of the lactol 5a led to the formation of katsumadain A as the only diastereoisomer in $52 \%$ yield,

Table 2: Substrate scope of organocatalytic 1,4-conjugate addition/hemiketalization of styryl-2-pyranones with $\alpha, \beta$-unsaturated aldehydes.

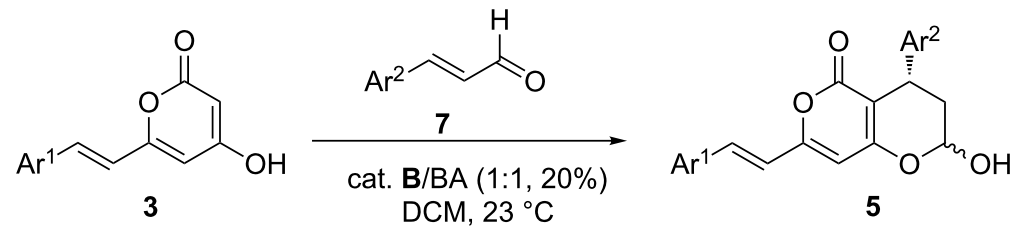

\begin{tabular}{|c|c|c|c|}
\hline Entrya & Substrate (3 and 7 ) & Yield of $5(\%)^{b}$ & ee value of $5(\%)^{c}$ \\
\hline 1 & 3a: $\mathrm{Ar}^{1}=\mathrm{Ph} ; \mathbf{7 a}: \mathrm{Ar}^{2}=\mathrm{Ph}$ & $82(5 a)$ & 92 \\
\hline 2 & 3a: $\mathrm{Ar}^{1}=\mathrm{Ph} ; \mathbf{7 b}: \mathrm{Ar}^{2}=4-\mathrm{Cl}-\mathrm{Ph}$ & $59(5 b)$ & 83 \\
\hline 3 & 3a: $\mathrm{Ar}^{1}=\mathrm{Ph} ; \mathbf{7 c}: \mathrm{Ar}^{2}=4-\mathrm{CF}_{3}-\mathrm{Ph}$ & $77(5 c)$ & 82 \\
\hline 4 & 3a: $\mathrm{Ar}^{1}=\mathrm{Ph} ; \mathbf{7 d}: \mathrm{Ar}^{2}=4-\mathrm{NO}_{2}-\mathrm{Ph}$ & $79(\mathbf{5 d})$ & 88 \\
\hline 5 & 3a: $\mathrm{Ar}^{1}=\mathrm{Ph} ; 7 \mathbf{e}: \mathrm{Ar}^{2}=4-\mathrm{MeO}-\mathrm{Ph}$ & $78(5 e)$ & 87 \\
\hline 6 & 3a: $\mathrm{Ar}^{1}=\mathrm{Ph} ; \mathbf{7 f :} \mathrm{Ar}^{2}=3,5-\mathrm{MeO}-\mathrm{Ph}$ & $70(\mathbf{5 f})$ & 92 \\
\hline 7 & 3b: $\mathrm{Ar}^{1}=4-\mathrm{MeO}-\mathrm{Ph} ; \mathbf{7 a}: \mathrm{Ar}^{2}=\mathrm{Ph}$ & $84(5 \mathrm{~g})$ & 82 \\
\hline 8 & 3c: $\mathrm{Ar}^{1}=$ Furan; $7 \mathrm{~b}: \mathrm{Ar}^{2}=4-\mathrm{Cl}-\mathrm{Ph}$ & $88(5 h)$ & 84 \\
\hline 9 & 3c: $\mathrm{Ar}^{1}=$ Furan; $7 \mathrm{~d}: \mathrm{Ar}^{2}=4-\mathrm{NO}_{2}-\mathrm{Ph}$ & $76(5 \mathbf{i})$ & 91 \\
\hline 10 & 3c: $\mathrm{Ar}^{1}=$ Furan; 7e: $\mathrm{Ar}^{2}=4-\mathrm{MeO}-\mathrm{Ph}$ & $75(5 \mathbf{j})$ & 80 \\
\hline 11 & 3c: $\mathrm{Ar}^{1}=$ Furan; $\mathbf{7 g}: \mathrm{Ar}^{2}=$ Naphthyl & $79(\mathbf{5 k})$ & 90 \\
\hline
\end{tabular}

aEach reaction was run with $3(0.5 \mathrm{mmol})$ and $7(0.6 \mathrm{mmol})$ in $2.0 \mathrm{~mL}$ solvent as shown above. beach of $5 \mathbf{a}-\mathbf{k}$ was obtained as a mixture of $\mathrm{C}-5 \mathrm{dia}-$ stereoisomers (the ratio of $\alpha$-isomer: $\beta$-isomer varied from 1:5 to 1:7. ${ }^{\mathrm{C}}$ The ee value of $\mathbf{5 a}-\mathbf{k}$ was measured with the corresponding lactone product using chiral HPLC. 
apparently via the in situ generated intermediate $\mathbf{8}$. The spectroscopic data of the synthetic katsumadain A were in accordance with those of the natural one [32]. However, we found that its optical rotation $\left([\mathrm{a}]_{\mathrm{D}}{ }^{25}=-75.4, c 0.40, \mathrm{EtOH}\right)$ was quite different from the reported one $\left([\mathrm{a}]_{\mathrm{D}}{ }^{25}+3.7, c 0.40\right.$, EtOH $)$ indicating that the naturally occurring 1 might exist as a racemic substance. Given that the two enantiomers of katsumadain A might show different behaviors in the biological studies from each other as well as from the racemic compounds, we also synthesized (+)-katsumadain A in a similar way by simply replacing the catatalyst $\mathbf{B}$ with its enantiomer in the organocatalytic 1,4-conjugate addition (Scheme 3).

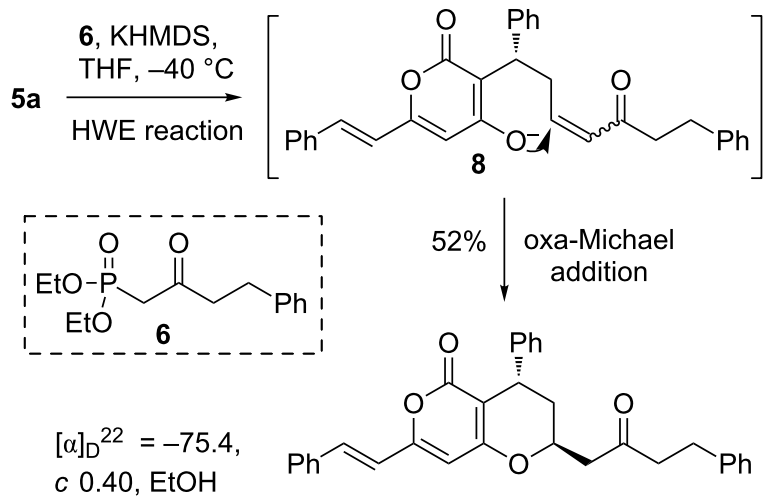

(-)-katsumadain A

$[\alpha]_{\mathrm{D}}^{22}=+79.0$,

c $0.20, \mathrm{EtOH}$<smiles>O=C(CCc1ccccc1)C[C@H]1C[C@H](c2ccccc2)c2c(cc(/C=C/c3ccccc3)oc2=O)O1</smiles>

(+)-katsumadain A

2) $6, \mathrm{KHMDS}, \mathrm{THF},-40^{\circ} \mathrm{C}$

Scheme 3: Total synthesis of both enantiomers of katsumadain A.

\section{Conclusion}

We accomplished the first enantioselective total synthesis of katsumadain A, a naturally occurring influenza virus neuraminidase (NA) inhibitor. The key elements of the synthesis featured a bioinspired, organocatalytic enantioselective 1,4-conjuate addition and a tandem HWE/oxa-Michael addition. Due to the high efficiency and flexibility of the synthetic route it is applicable to the syntheses of both enantiomers of katsumadain A as well as their analogues. Applications of these compounds in relevant biomedical studies are ongoing in this laboratory, and the progress will be reported in due course.

\section{Experimental}

Representative procedure for the organocatalytic 1,4-conjugate addition: To a mixture of $\mathbf{3 a}(214 \mathrm{mg}, 1.0 \mathrm{mmol})$ and $7 \mathbf{a}$ (163 mg, $1.2 \mathrm{mmol}$ ) in dry $\mathrm{CH}_{2} \mathrm{Cl}_{2}(5 \mathrm{~mL})$ at $0{ }^{\circ} \mathrm{C}$ was added $\mathrm{PhCOOH}(24 \mathrm{mg}, 0.2 \mathrm{mmol})$ and catatalyst $\mathbf{B}(50 \mathrm{mg}$, 0.2 equiv). The mixture was stirred at $0{ }^{\circ} \mathrm{C}$ for $10 \mathrm{~h}$ before being quenched by saturated aqueous $\mathrm{NH}_{4} \mathrm{Cl}$. The mixture was extracted with DCM $(3 \times 10 \mathrm{~mL})$, and the organic layers were washed with brine and dried over $\mathrm{MgSO}_{4}$. The organic solvent was removed under vacuum, and the residue was purified by column chromatography $\left(\mathrm{CH}_{2} \mathrm{Cl}_{2}\right.$ :ethyl acetate $\left.=20: 1\right)$ to give 5a (284 mg, 82\% yield) as a light yellow solid.

\section{Supporting Information}

\section{Supporting Information File 1}

Experimental procedures and characterization data for synthetic 1, 3a-c, 5a-k and $\mathbf{9 a}-\mathbf{k}$.

[http://www.beilstein-journals.org/bjoc/content/ supplementary/1860-5397-9-182-S1.pdf]

\section{Acknowledgements}

This work was financially supported by the National Science Foundation of China $(21102081,21272133)$, the Beijing Natural Science Foundation (2132037), the New Teachers' Fund for Doctor Stations (20110002120011), the Scientific Research Foundation for the Returned Overseas Chinese Scholars, and the Ministry of Education.

\section{References}

1. McGlacken, G. P.; Fairlamb, I. J. S. Nat. Prod. Rep. 2005, 22, 369-385. doi:10.1039/b416651p

2. Goel, A.; Ram, V. J. Tetrahedron 2009, 65, 7865-7913. doi:10.1016/j.tet.2009.06.031

3. Yang, Y.; Kinoshita, K.; Koyama, K.; Takahashi, K.; Tai, T.; Nunoura, Y.; Watanabe, K. J. Nat. Prod. 1999, 62, 1672-1674. doi:10.1021/np990096e

4. Grienke, U.; Schmidtke, M.; Kirchmair, J.; Pfarr, K.; Wutzler, P.; Dürrwald, R.; Wolber, G.; Liedl, K. R.; Stuppner, H.; Rollinger, J. M. J. Med. Chem. 2010, 53, 778-786. doi:10.1021/jm901440f

5. Kirchmair, J.; Rollinger, J. M.; Liedl, K. R.; Seidel, N.; Krumbholz, A.; Schmidtke, M. Future Med. Chem. 2011, 3, 437-450. doi:10.4155/fmc.10.292

6. Grienke, U.; Schmidtke, M.; von Grafenstein, S.; Kirchmair, J.; Liedl, K. R.; Rollinger, J. M. Nat. Prod. Rep. 2012, 29, 11-36. doi:10.1039/c1np00053e

7. Zhang, P.; Wang, Y.; Bao, R.; Luo, T.; Yang, Z.; Tang, Y. Org. Lett. 2012, 14, 162-165. doi:10.1021/ol2029433

8. Yang, C.-S.; Wang, X.-B.; Wang, J.-S.; Luo, J.-G.; Luo, L.; Kong, L.-Y. Org. Lett. 2011, 13, 3380-3383. doi:10.1021/ol201137v

9. Kuroyanagi, M.; Noro, T.; Fukushima, S.; Aiyama, R.; Ikuta, A.; Itokawa, H.; Morita, M. Chem. Pharm. Bull. 1983, 31, 1544-1550. doi:10.1248/cpb.31.1544 
10. Csákÿ, A. G.; de la Herrán, G.; Murcia, M. C. Chem. Soc. Rev. 2010, 39, 4080-4102. doi:10.1039/b924486g

11. Silva, E. M. P.; Silva, A. M. S. Synthesis 2012, 44, 3109-3128. doi:10.1055/s-0032-1316778

12. den Hartog, T.; Harutyunyan, S. R.; Font, D.; Minnaard, A. J.; Feringa, B. L. Angew. Chem., Int. Ed. 2008, 47, 398-401. doi:10.1002/anie.200703702

13. Bernardi, L.; López-Cantarero, J.; Niess, B.; Jørgensen, K. A. J. Am. Chem. Soc. 2007, 129, 5772-5778. doi:10.1021/ja0707097

14. Murphy, J. J.; Quintard, A.; McArdle, P.; Alexakis, A.; Stephens, J. C. Angew. Chem., Int. Ed. 2011, 50, 5095-5098. doi:10.1002/anie.201100804

15. Tian, X.; Liu, Y.; Melchiorre, P. Angew. Chem., Int. Ed. 2012, 51, 6439-6442. doi:10.1002/anie.201202392

16. McLeod, M. C.; Wilson, Z. E.; Brimble, M. A. Org. Lett. 2011, 13, 5382-5385. doi:10.1021/ol202265g

17. Katritzky, A. R.; Wang, Z.; Wang, M.; Hall, C. D.; Suzuki, K. J. Org. Chem. 2005, 70, 4854-4856. doi:10.1021/jo050307m

18. Baranovsky, A.; Schmitt, B.; Fowler, D. J.; Schneider, B. Synth. Commun. 2003, 33, 1019-1045. doi:10.1081/SCC-120016367

19. Wang, J.-J.; Hu, Z.-P.; Lou, C.-L.; Liu, J.-L.; Li, X.-M.; Yan, M. Tetrahedron 2011, 67, 4578-4583. doi:10.1016/j.tet.2011.04.086

20. Zhu, X.; Lin, A.; Shi, Y.; Guo, J.; Zhu, C.; Cheng, Y. Org. Lett. 2011, 13, 4382-4385. doi:10.1021/ol201715h

21. Li, X.-M.; Wang, B.; Zhang, J.-M.; Yan, M. Org. Lett. 2011, 13, 374-377. doi:10.1021/ol102570b

22. Xie, J.-W.; Yue, L.; Chen, W.; Du, W.; Zhu, J.; Deng, J.-G.; Chen, Y.-C. Org. Lett. 2007, 9, 413-415. doi:10.1021/ol062718a

23. Liu, Y.; Liu, X.; Wang, M.; He, P.; Lin, L.; Feng, X. J. Org. Chem. 2012, 77, 4136-4142. doi:10.1021/jo3001047

24. Erkkilä, A.; Majander, I.; Pihko, P. M. Chem. Rev. 2007, 107, 5416-5470. doi:10.1021/cr068388p

25. Almasi, D.; Alonso, D. A.; Nájera, C. Tetrahedron: Asymmetry 2007, 18, 299-365. doi:10.1016/j.tetasy.2007.01.023

26. Tsogoeva, S. B. Eur. J. Org. Chem. 2007, 1701-1716. doi:10.1002/ejoc.200600653

27. Rueping, M.; Merino, E.; Sugiono, E. Adv. Synth. Catal. 2008, 350, 2127-2131. doi:10.1002/adsc.200800340

28. Hayashi, Y.; Gotoh, H.; Hayashi, T.; Shoji, M. Angew. Chem., Int. Ed. 2005, 44, 4212-4215. doi:10.1002/anie.200500599

29. Marigo, M.; Wabnitz, T. C.; Fielenbach, D.; Jørgensen, K. A. Angew. Chem., Int. Ed. 2005, 44, 794-797. doi:10.1002/anie.200462101

30. Austin, J. F.; MacMillan, D. W. C. J. Am. Chem. Soc. 2002, 124, 1172-1173. doi:10.1021/ja017255c

31. Maloney, K. M.; Chung, J. Y. L. J. Org. Chem. 2009, 74, 7574-7576. doi:10.1021/jo901552k

32. The ee value of the synthetic (+)-1and (-)-1 was determined to be $80 \%$ and $81 \%$, respectively, suggesting that partial racemization occurred in the HWE reaction, presumably via the intermediate $\mathbf{8}$.

\section{License and Terms}

This is an Open Access article under the terms of the Creative Commons Attribution License

(http://creativecommons.org/licenses/by/2.0), which permits unrestricted use, distribution, and reproduction in any medium, provided the original work is properly cited.

The license is subject to the Beilstein Journal of Organic Chemistry terms and conditions:

(http://www.beilstein-journals.org/bjoc)

The definitive version of this article is the electronic one which can be found at:

doi:10.3762/bjoc. 9.182 